\title{
Pengaruh Penguasaan Kalimat Efektif Terhadap Kemampuan Menulis Karangan Narasi Pada Siswa
}

\author{
Hamidah Apriani ${ }^{1 *}$ \\ Fauzi Rahman ${ }^{1}$ \\ Ryan Hidayat ${ }^{1}$ \\ ${ }^{1}$ Universitas Indraprasta PGRI, \\ Jakarta Timur, Jakarta, Indonesia \\ *email: \\ hamidahapriani09@gmail.com
}

Received: 5 Februari 2020

Accepted: 16 Maret 2020

Published: 26 Maret 2020

doi:

http://dx.doi.org/10.29405/imj.v2i2

.68

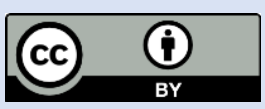

(C) 2020 Oleh authors. Lisensi Imajeri: Jurnal Pendidikan Bahasa dan Sastra Indonesia, Uhamka, Jakarta. Artikel ini bersifat open access yang didistribusikan di bawah syarat dan ketentuan Creative Commons Attribution (CC-BY) license.

(http://creativecommons.org/licens es/by/4.0/).

\begin{abstract}
Abstrak
Penelitian bertujuan untuk mengetahui pengaruh penguasaan kalimat efektif terhadap kemampuan menulis karangan narasi siswa. Penelitian ini menggunakan metode survei dengan menggunakan teknis analisis korelasional. Sampel penelitian berjumlah 70 orang siswa yang dipilih secara random dari seluruh siswa kelas VII SMP. Teknik analisis statistik yang digunakan adalah statistika deksriptif untuk mencari rata-rata, median, modus, standar deviasi dan histogram, dan teknik statistika inferensial yaitu untuk mengetahui besaran skor hubungan dan sumbangan variabel bebas terhadap variabel terikat kemudian dilanjutkan dengan uji t untuk mengetahui signifikansi hubungan antarvariabel tersebut. Berdasarkan hasil penelitian, dapat disimpulkan bahwa: terdapat pengaruh yang signifikan penguasaan kalimat efektif terhadap kemampuan menulis karangan narasi, hal tersebut dibuktikan dengan sig. $0,045<0,05$ dan thitung $=2,084$, Artinya, penguasaan kalimat efektif terbukti memiliki pengaruh positif terhadap kemampuan menulis karangan narasi siswa.
\end{abstract}

Kata kunci: Penguasaan Kalimat Efektif; Kemampuan Menulis Karangan Narasi

\section{Abstract}

The study aims to determine the effect of effective sentence mastery on students' narrative essay writing skills. This study uses a survey method using correlational technical analysis. The research sample consisted of 70 students who were randomly selected from all seventh grade students of SMP. Statistical analysis techniques used are descriptive statistics to look for averages, medians, modes, standard deviations and histograms, and inferential statistics techniques to determine the magnitude of the relationship score and the contribution of independent variables to the dependent variable then proceed with the $t$ test to determine the significance of the relationship between variables the. Based on the results of the study, it can be concluded that: there is a significant effect of effective sentence mastery on the ability to write a narrative essay, this is evidenced by sig. $0.045<0.05$ and tcount $=2.084$, meaning that the mastery of effective sentences is proven to have a positive influence on the ability to write students' narrative essays.

Keywords: Effective Sentence Mastery; Ability to Write Narrative Essays

\section{PENDAHULUAN}

Pada era globalisasi sekarang ini pelaksanaan sistem pendidikan semakin beraneka ragam bentuknya. Sistem pembelajarannyapun ikut berkembang seiring dengan kemajuan teknologi komunikasi dan informasi. Bahasa adalah salah satu alat komunikasi. Melalui bahasa, kita dapat saling berhubungan (komunikasi), saling berbagi pengalaman, saling belajar dari yang lain dan dapat meningkatkan kemampuan intelektual. Keberadaan bahasa menyebabkan manusia dapat memahami dan mengungkapkan informasi, pikiran, perasaan, serta 
mengembangkan ilmu pengetahuan, teknologi, budaya, dan memperluas wawasan berpikir. Maka pelajaran Bahasa dan Sastra Indonesia adalah program untuk mengembangkan pengetahuan, keterampilan berbahasa dan sikap positif terhadap bahasa Indonesia.

Bahasa diartikan sebagai sistem lambang bunyi yang arbitrer, yang digunakan oleh anggota suatu masyarakat untuk bekerja sama, berinteraksi dan mengidentifikasi diri (Yanti dkk., 2017). Lebih lanjut, Ahmad (2008:13) berpendapat bahwa bahasa adalah alat komunikasi antara anggota masyarakat berupa lambang bunyi ujaran yang dihasilkan oleh alat ucap manusia.

Dengan demikian tidak dapat dipungkiri betapa pentingnya bahasa bagi kehidupan manusia terutama sebagai sarana untuk berkomunikasi baik secara lisan maupun tulisan. Komunikasi dalam bentuk tulisan tentu menuntut para pembelajar untuk terampil dalam menuangkan ide dan pikiran dalam bentuk tulisan untuk menciptakan komunikasi secara tidak langsung, sehingga apa yang tertuang dapat dimengerti dan bermakna bagi para penikmat tulisan tersebut. Untuk menciptakan karya tulis yang sarat makna tentunya para penulis harus terampil dan mengerti aturan-aturan dalam hal menulis.

Sehubungan dengan penggunaan bahasa, terdapat empat keterampilan dasar berbahasa, yaitu mendengarkan (menyimak), berbicara, membaca, dan menulis (Mulyati, 2008:1.10). Setiap keterampilan itu erat sekali berhubungan dengan tiga keterampilan lainnya dengan cara yang beraneka ragam. Dalam memperoleh keterampilan berbahasa, biasanya melalui suatu hubungan urutan yang teratur: mula-mula pada masa kecil, seorang anak belajar menyimak bahasa, kemudian berbicara, sesudah itu belajar membaca dan menulis. Keempat keterampilan tersebut pada dasarnya merupakan satu kesatuan, merupakan catur-tunggal (Tarigan, 2008:1).

Menulis merupakan salah satu keterampilan berbahasa, yaitu suatu cara berkomunikasi antara individu dengan individu lainnya. Melalui tulisan, seseorang dapat menceritakan kembali kejadian atau pengalaman yang pernah dialaminya, melukiskan sesuatu yang pernah dilihat, dirasa, diraba, dan didengarnya. Melalui tulisan, seseorang juga dapat menyampaikan gagasan, ide, dan pikirannya (Rahman, 2018).

Pada pembelajaran bahasa Indonesia ada empat keterampilan berbahasa yang akan diajarkan oleh guru bidang studi ini, komponen-komponennya yaitu, keterampilan menyimak, berbicara, membaca, dan menulis. Berdasarkan pengalaman sebagai pengajar, dari keempat keterampilan tersebut, jika diperhatikan sisi terlemah yang dialami siswa adalah aspek keterampilan menulis, masih banyak kesalahan yang dilakukan siswa dalam mengarang yaitu masih adanya penggunaan kalimat yang tidak efektif.

Kita dapat melihat bahwa pekerjaan menulis bukan hal yang mudah, tentunya tidak dapat dilakukan oleh semua individu, disamping memerlukan pengetahuan yang cukup dalam hal menulis, juga keterampilan dan minat seseorang pada bidang ini juga turut berperan untuk dapat menciptakan suatu tulisan yang bermakna, baik bagi penulisnya maupun pembaca tulisan itu sendiri.

Pengajaran sastra mempunyai peranan penting dan mempengaruhi watak, kepribadian, memperluas wawasan kehidupan, dan meningkatkan kemampuan berbahasa pada siswa, baik secara lisan maupun tulis. Dalam penerapannya pengajaran sastra bukan hanya pengajaran 
mengenai teori-teori sastra, tetapi siswa dituntut untuk mengungkapkan pikiran dan perasaannya melalui karya sastra (Depdiknas 2006:4).

Pengajaran sastra berupa pembelajaran apresiasi sastra dan pembelajaran ekspresi sastra. Pembelajaran ekspresi sastra ada dua macam yaitu ekspresi lisan dan ekspresi tulis. Tujuan pembelajaran ekspresi tulis sastra adalah agar siswa mampu mengungkapkan pengalamannnya dalam bentuk sastra tulis. Dalam hal ini siswa diasah kepekaannya terhadap lingkungan dan mampu mengungkapkannya dalam karangan tertulis, baik dalam bentuk prosa maupun bentuk puisi. Tujuan lain pembelajaran ekspresi tulis sastra adalah agar siswa memiliki kegemaran menulis karya sastra untuk meningkatkan pengetahuan dan memanfaatkannya dalam kegiatan sehari-hari.

Menulis karangan narasi merupakan salah satu kompetensi dasar dari kemampuan bersastra kelas VII SMP. Siswa diharapkan mampu mengungkapkan pikiran, gagasan, dan perasaan dalam bentuk karya sastra yaitu dalam menulis karangan narasi. Dalam menulis perlu memilih bahasa yang bisa mewakili perasaan, pikiran, dan keinginan, yang dituangkan dalam bentuk cerita, tetapi dalam pengajaran bahasa Indonesia, materi yang dirasa sulit oleh para siswa justru menulis terutama menulis karangan narasi. Maka atas dasar inilah penulis meneliti tentang karangan narasi siswa SMP kelas VII.

Lebih lanjut seperti yang dikemukakan Iskandar dan Sunendar (2011:248), bahwa dibandingkan dengan tiga kemampuan berbahasa yang lain, kemampuan menulis lebih sulit dikuasai bahkan oleh penutur asli bahasa yang bersangkutan sekalipun. Hal ini disebabkan kemampuan menulis menghendaki penguasaan berbagai unsur kebahasaan dan unsur di luar bahasa itu sendiri yang menjadi isi tulisan.

Dalam pelaksanaannya, pembelajaran menulis karangan narasi belum sepenuhnya berjalan dengan baik. Pembelajaran menulis karangan narasi di sekolah masih banyak kendala dan cenderung dihindari. Siswa mengalami kesulitan dalam menulis karangan narasi karena belum mampu dalam menentukan tema dan membayangkan hal-hal yang akan ditulis. Selain itu penguasaan kalimat efektif yang masih kurang.

Pentingnya penguasaan kalimat efektif bagi seorang siswa bukan hanya dapat membantu proses daya pikirnya, akan tetapi dapat pula mengembangkan kreativitas dalam kegiatan menulis. Bila seorang siswa membuat tulisan, maka ia memulai dengan menyusun kata-kata secara teratur sehingga menjadi sebuah kalimat, kemudian menyusun kalimat-kalimat sehingga menjadi sebuah paragraf, dan selanjutnya menyusun paragraf-paragraf itu sehingga menjadi karangan (wacana). Penguasaan kalimat efektif memegang peranan penting dan utama, karena dengan perbendaharaan kalimat efektif akan membantu menentukan pilihan kata yang tepat pada tulisan yang dibuat.

Berbagai permasalahan yang dihadapi siswa yaitu (1) siswa masih belum maksimal dalam memahami materi yang diberikan oleh guru, (2) siswa tidak bisa bebas menulis karangan narasi, karena kurangnya inspirasi yang diberikan oleh guru, dan (3) kurangnya pemanfaatan media pembelajaran yang sebenarnya bisa membangkitkan semangat belajar siswa. Pembelajaran juga tidak sepenuhnya terpusat pada guru sehingga memberikan kesempatan pada siswa untuk aktif dan kreatif. Selain itu, Masalah utama yang dihadapi siswa adalah sulit menentukan pilihan kata, menggabungkan kalimat dan menuangkan ide dalam 
tulisan narasi. Kesulitan ini menyebabkan rendahnya kualitas tulisan siswa baik pada aspek isi maupun kebahasaan (Farida, 2009).

Dalam pembelajaran menulis karangan narasi, hal yang harus diperhatikan adalah kemampuan siswa untuk mencoba berkarya menulis dengan kemampuan yang sudah dimiliki sehinggga terlihat manfaat pengajaran yang diberikan pada siswa di sekolah. Kemampuan menulis karangan narasi tidak lahir begitu saja tetapi sebelumnya siswa harus belajar, memiliki kemauan, kemampuan dan pengalaman, serta penguasaan kalimat efektif, sehingga siswa mampu untuk menulis karangan narasi.

Kenyataannya pada SMP Swasta di Kota Bogor ada gejala tidak semua siswa yang penguasaan kalimat efektifnya baik, kemampuan mengarang narasinya memuaskan, dan sebaliknya tidak semua siswa yang penguasaan kalimat efeltifnya rendah, hasil karangan narasinya mengecewakan. Keadaan inilah yang membuat penulis tertarik untuk melakukan penelitian pada SMP Swasta di Kota Bogor.

Tujuan penelitian ini adalah untuk mengetahui pengaruh penguasaan kalimat efektif terhadap kemampuan menulis karangan narasi siswa SMP Swasta di Kota Bogor.

\section{METODE}

Penelitian dilakukan pada SMP Swasta di Kota Bogor. Sedangkan objek penelitian atau yang akan menjadi sasaran dalam penelitian ini adalah siswa-siswa kelas VII SMP tersebut. Pelaksanaan penelitian dijadwalkan selama empat bulan yang terhitung dari mulai persetujuan proposal dan diperkirakan mulai bulan Februari sampai dengan bulan April. Waktu penelitiannya dilaksanakan pada semester II (genap).

Penelitian ini menggunakan metode kuantitatif dengan mengkaji fakta-fakta yang terjadi secara empiris. Penelitian ini dikategorikan sebagai penelitian deskriptif korelasional karena berusaha memaparkan hubungan faktor atau variabel-variabel yang memengaruhi keadaan tanpa memanipulasi variabel tersebut.

Data-data dalam penelitian ini diperoleh berdasarkan pemberian instrumen soal tentang penguasaan kalimat efektif dan pemberian instrumen kemampuan menulis karangan narasi pada SMP Swasta di Kota Bogor.

Teknik analisis dalam penelitian ini dilakukan melalui analisis korelasi dan regresi guna melihat pengaruh variabel bebas (X) terhadap (Y). Adapun model konstelasi dari hubungan antar variabel pada penelitian ini adalah sebagai berikut:

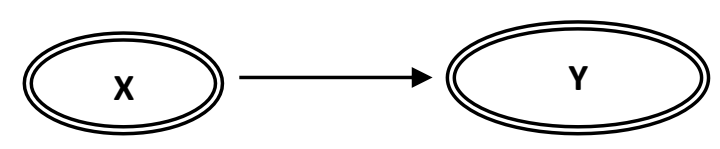

Gambar 1. Model Konstelasi dari hubungan antara variabel.

Keterangan:

Variabel X: Penguasaan Kalimat Efektif

Variabel Y: Kemampuan Menulis Karangan Narasi

Populasi target penelitian adalah seluruh objek dengan karakterisik tertentu yang terdapat dalam daerah penelitian. Populasi dalam penelitian ini adalah para siswa kelas VII yang 
berada di SMP Swasta di Kota Bogor yang masing-masing sekolah mempunyai 9 kelas dengan jumlah siswa sebanyak 470 siswa.

Dalam penelitian ini digunakan teknik pemilihan sampel yang menggunakan teknik gabungan antara cluster, proporsional dan random. Teknik cluster digunakan dalam pengelompokan siswa menurut tempat sekolah belajar. Dalam menentukan jumlah anggota sampel digunakan teknik proporsional dari setiap kelas yang ada pada populasi. Sedangkan untuk menentukan anggota sampel dari setiap kelas yang ada digunakan teknik random. Jumlah anggota sampel dalam penelitian ini ditetapkan sebanyak 70 siswa, yaitu sebanyak $15 \%$ dari jumlah populasi (470 siswa). Jadi penetapan jumlah anggota sampel dari setiap sekolah atau cluster sebanyak 35 siswa.

Secara rinci sumber data dalam penelitian ini adalah:

a. Untuk penguasaan kalimat efektif $(\mathrm{X})$ berasal dari jawaban pemberian tes instrumen soal yang diberikan oleh peneliti.

b. Untuk kemampuan menulis karangan narasi (Y) berasal dari pemberian tes instrumen soal yang diberikan oleh peneliti

\section{HASIL DAN PEMBAHASAN}

\section{Deskripsi Data}

Jumlah responden dalam penelitian di SMP Swasta di Kota Bogor sebanyak 70 orang siswa yang dijadikan sampel penelitian dan 20 orang siswa sebagai responden untuk uji coba instrumen. Data hasil penelitian dapat ditampilkan dalam bentuk statistika deskriptif secara berurutan sebagai berikut:

1. Data Variabel Kemampuan Menulis Karangan Narasi (Y)

Dari hasil penelitian ke lapangan dengan melakukan tes terhadap sampel penelitian yang berjumlah 70 siswa diperoleh rentang skor interval antara 30 sampai 81, rata-rata skor 67,42 , median 67,50, modus 66,00 dan standar deviasi sebesar 6,85. Hasil perhitungan lengkap dapat dilihat pada tabel berikut:

Tabel 1. Perhitungan Statistika Deskriptif Variabel Menulis Karangan Narasi

\begin{tabular}{|l|l|}
\hline \multicolumn{1}{|c|}{$\quad$ Valid } & Y \\
\hline N Missing & 0 \\
Mean & 67.4286 \\
Median & 67.5000 \\
Mode & $66.00^{\mathrm{a}}$ \\
Std. Deviation & 6.85581 \\
Variance & 47.002 \\
Range & 30.00 \\
Maximum & 81.00 \\
Sum & 4720.00 \\
\hline
\end{tabular}

Bentuk sebaran data penelitian tersebut di atas, dapat digambarkan dalam histogram sebagai berikut: 


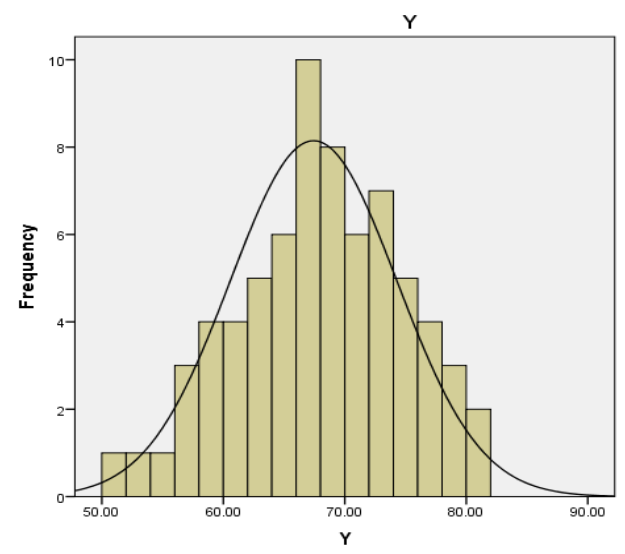

Gambar 2. Grafik Menulis Karangan Narasi

Pada gambar histogram di atas terlihat seimbang antara jumlah responden yang memiliki skor rendah dengan responden yang memiliki skor tinggi sehingga membentuk kurva normal atau dapat dikatakan bahwa data hasil penelitian variabel kemampuan menulis karangan narasi siswa berdistribusi normal.

2. Data Variabel Penguasaan Kalimat Efektif (X)

Dari hasil penelitian ke lapangan dengan melakukan tes penguasaan kalimat efektif terhadap sampel penelitian yang berjumlah 70 siswa diperoleh rentang skor interval dari 30 sampai 75, rata-rata skor (Mean) 60,55; modus (Modus) 61,00; median (Median) 61,00 dan standar deviasi (Std) sebesar 7,55. Hasil perhitungan lengkap dapat dilihat pada tabel berikut:

Tabel 2. Perhitungan Statistika Deskriptif Variabel Penguasaan Kalimat Efektif

\begin{tabular}{|c|c|c|}
\hline & & $\mathrm{x}$ \\
\hline \multirow[t]{2}{*}{$\mathrm{N}$} & Valid & 70 \\
\hline & Missing & 0 \\
\hline \multicolumn{2}{|c|}{ Mean } & 60.5571 \\
\hline \multicolumn{2}{|c|}{ Median } & 61.0000 \\
\hline \multicolumn{2}{|c|}{ Mode } & 61.00 \\
\hline \multicolumn{2}{|c|}{ Std. Deviation } & 7.55201 \\
\hline \multicolumn{2}{|c|}{ Variance } & 57.033 \\
\hline \multicolumn{2}{|c|}{ Range } & 30.00 \\
\hline \multicolumn{2}{|c|}{ Maximum } & 75.00 \\
\hline \multicolumn{2}{|c|}{ Sum } & 4239.00 \\
\hline
\end{tabular}

Bentuk sebaran data penelitian tersebut di atas, dapat digambarkan dalam histogram sebagai berikut: 


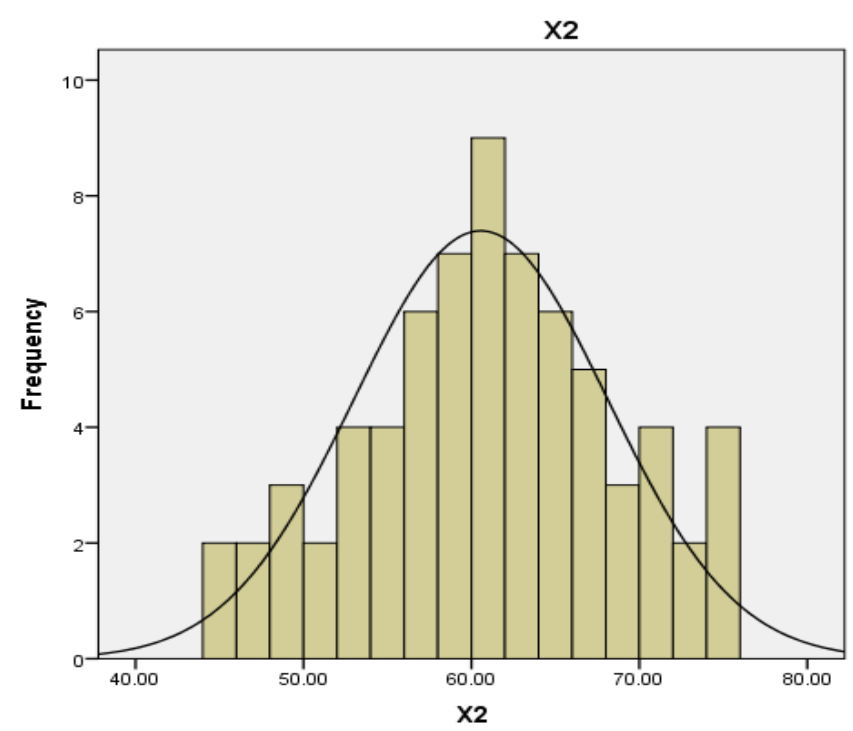

Gambar 3. Grafik Penguasaan Kalimat Efektif

Pada gambar histogram di atas terlihat seimbang antara jumlah responden yang memiliki skor rendah dengan responden yang memiliki skor tinggi sehingga membentuk kurva normal atau dapat dikatakan bahwa data hasil penelitian variabel penguasaan kalimat efektif berdistribusi normal.

B. Pengujian Hipotesis Penelitian

Untuk melakukan uji hipotesis, maka perlu ditampilkan tabel hasil perhitungan sebagai berikut:

Tabel 3. Signifikansi Koefisien Regresi Pengaruh Penguasaan Kalimat Efektif (X) Terhadap Kemampuan Menulis Karangan Narasi (Y)

Coefficients $^{\mathrm{a}}$

\begin{tabular}{|c|c|c|c|c|c|}
\hline \multirow[b]{2}{*}{ Model } & \multicolumn{2}{|c|}{$\begin{array}{l}\text { Unstandardized } \\
\text { Coefficients }\end{array}$} & \multirow{2}{*}{$\begin{array}{c}\begin{array}{c}\text { Standardized } \\
\text { Coefficients }\end{array} \\
\text { Beta }\end{array}$} & \multirow[b]{2}{*}{$\mathrm{t}$} & \multirow[b]{2}{*}{ Sig. } \\
\hline & B & Std. Error & & & \\
\hline (Constant) & 37.893 & 7.494 & & 5.057 & .000 \\
\hline $\mathrm{X}$ & .204 & .103 & .225 & 2.084 & .045 \\
\hline
\end{tabular}

Pada Tabel 3. diperoleh skor persamaan regresi, koefisien korelasinya $\hat{Y}=37,89+$ $0,204 X$, skor thitung variabel $\mathrm{X}=2,084$ yang menunjukkan adanya hubungan variabel bebas dengan variabel terikat.

Persamaan regresi variabel penguasaan kalimat efektif dengan kemampuan menulis karangan narasi ditampilkan bentuk persamaan regresi linear berbentuk $\hat{Y}=37,89+0,204 X$. Persamaan regresi ini memiliki arti bahwa setiap kenaikan satu unit penguasaan kalimat efektif maka akan memberikan kontribusi terhadap kenaikan kemampuan menulis karangan narasi sebesar 0,204.

Hipotesis penelitian pengaruh penguasaan kalimat efektif terhadap kemampuan menulis karangan narasi adalah "Terdapat pengaruh positif penguasaan kalimat efektif 
terhadap kemampuan menulis karangan narasi." Untuk membuktikan hipotesis yang diuji dengan memperhatikan skor pada yang tertera pada kolom "t" atau kolom Sig tabel di atas. Menurut kerentuan bahwa jika skor Sig. > 0,05 maka Ho diterima artinya regresi tidak signifikan, jika sebaliknya skor Sig. $<0,05$ maka Ho ditolak artinya regresi signifikan. Apabila t hitung lebih besar dari t table dan skor Sig. 0,000 < 0,05 maka Ho ditolak dan Ha diterima yang berarti koefisien regresi signifikan, sedangkan bila sebaliknya maka regresi tidak signifikan.

Hasil pengujian keberartian atau signifikansi koefisien korelasi sederhana dijelaskan pada tabel di atas, diperoleh sig. 0,045 $<0,05$ dan thitung $=2,084$, maka Ho ditolak dan Ha diterima, artinya terdapat pengaruh penguasaan kalimat efektif terhadap kemampuan menulis karangan narasi signifikan.

Dari hasil perhitungan koefisien korelasi di atas, dapat disimpulkan bahwa terdapat pengaruh positif dan signifikan penguasaan kalimat efektif terhadap kemampuan menulis karangan narasi siswa. Artinya jika kita hendak meningkatkan kemampuan menulis karangan narasi siswa, maka terlebih dahulu harus ditingkatkan penguasaan kalimat efektif.

\section{Pembahasan Hasil Penelitian}

Hasil penelitian adanya pengaruh penguasaan kalimat efektif terhadap kemampuan menulis karangan narasi siswa, artinya bahwa setiap kenaikan satu skor penguasaan kalimat efektif akan diikuti dengan kenaikan kemampuan menulis karangan narasi siswa. Dengan demikian jika kita hendak meningkatkan kemampuan menulis karangan narasi siswa maka terlebih dahulu harus ditingkatkan penguasaan kalimat efektif.

Temuan penelitian di atas sejalan dengan teori yang dikemukakan Hasnun (2005:8) mengemukakan bahwa sebuah kalimat efektif hendaklah mendukung satu gagasan atau ide. Agar gagasan atau ide kalimat mudah dipahami pembaca, fungsi bagian kalimat yang meliputi subjek, predikat, objek, dan keterangan, harus tampak jelas (eksplisit) dan juga kalimat harus dirakit secara logis dan teratur. Jika siswa sudah menguasai kalimat efektif maka kemampuan menulis karangan narasinya semakin baik.

Sementara itu, menurut Arifin (2000:84) kalimat efektif adalah kalimat yang memenuhi kriteria jelas, sesuai dengan kaidah, ringkas dan enak dibaca. Oleh karena itu, kalimat efektif sangat penting dalam penulisan karangan karena kalimat yang efektif akan menyampaikan gagasan atau pokok pikiran dengan jelas.

Dengan demikian, teori yang dikemukakan di atas menjadi penegasan bahwa penguasaan kalimat efektif berkaitan erat dengan kemampuan siswa dalam menulis, seperti halnya hasil penelitian ini yang menunjukkan bahwa penguasaan kalimat efektif memiliki pengaruh positif terhadap kemampuan menulis karangan narasi.

\section{SIMPULAN}

Berdasarkan deskripsi data penelitian dan dilakukan setelah analisis maka dapat disimpulkan bahwa terdapat pengaruh yang signifikan penguasaan kalimat efektif terhadap kemampuan menulis karangan narasi siswa SMP Swasta di Kota Bogor. Hal ini dibuktikan dengan sig. $0,045<0,05$ dan $t_{\text {hitung }}=2,084$.

Dengan demikian, penguasaan kalimat efektif terbukti memiliki pengaruh positif terhadap kemampuan menulis karangan narasi siswa SMP swasta di Kota Bogor. Sedangkan dari perhitungan analisis regresi diperoleh persamaan garis regresi: $\hat{\mathrm{Y}}=37,89+0,204 \mathrm{X}$. 
Berdasarkan simpulan hasil pengujian hipotesis penelitian dan analisis pengolahan data, maka implikasi dalam penelitian ini sebagai berikut: hasil penelitian menunjukkan pengaruh signifikan penguasaan kalimat efektif terhadap kemampuan menulis karangan narasi. Oleh karena itu, untuk meningkatkan kemampuan siswa dalam hal menulis karangan narasi dapat dilakukan dengan meningkatkan penguasaan kalimat efektif.

Upaya meningkatkan penguasaan kalimat efektif ialah guru harus menciptakan kegiatan pembelajaran yang aktif, kreatif, dan menyenangkan di dalam kelas. Sehingga pembelajaran mudah dipahami dan diterima oleh siswa. Apabila penguasaan kalimat efektif meningkat, maka siswa akan berupaya untuk mendapatkan nilai pelajaran bahasa Indonesia, terutama nilai menulis karangan narasi secara optimal.

Pada bagian akhir dalam penulisan ini, penulis ingin memberikan saran-saran terkait dengan hasil temuan penelitian sebagai berikut:

1. Kepada seluruh guru mata pelajaran Bahasa Indonesia agar banyak menggunakan model pembelajaran yang interaktif dan menyenangkan, yang mendorong siswa agar lebih mudah memahami materi tentang penguasaan kalimat efektif, sehingga mereka akan berpartisipasi aktif selama pembelajaran dan pada akhirnya proses belajar mengajar berhasil mencapai tujuan.

2. Kepada kepala sekolah, agar memberikan peluang dan dukungan kepada seluruh guru untuk dapat mengembangkan kompetensinya dengan penggunaan metode pembelajaran kolaboratif dan interaktif seiring dengan perkembangan dan perubahan zaman.

3. Kepada para peneliti yang hendak melakukan penelitian tentang penguasaan kalimat efektif terhadap kemampuan menulis karangan narasi atau penelitian pada mata pelajaran lainnya agar dapat melakukan pengkajian lebih dalam dengan menggunakan instrument atau alat pengumpul data bentuk lainnya sehingga dapat menguatkan temuan penelitian yang sudah ada.

Hasil penelitian ini diharapkan menjadi sumber bacaan dan literatur bagi para guru, siswa, dan khalayak lainnya yang berminat terhadap kajian tentang penguasaan kalimat efektif terhadap kemampuan menulis karangan narasi seperti penelitian di atas.

\section{DAFTAR PUSTAKA}

Arifin, dkk. (2000). Petunjuk Praktis Menulis. Jakarta: Depdikbud.

Depdiknas. (2006). Standar Kompetensi Mata Pelajaran Bahasa dan Sastra Indonesia SMP/MTs. Jakarta: Depdiknas.

Farida, D. (2009). Peningkatan Kemampuan Menulis Karangan Narasi dengan Menggunakan Media Kartun Berseri bagi Siswa Kelas III MI Tarbiyatul Islamiyah Kesambi Lamongan". Jurusan Sastra Indonesia-Fakultas Sastra UM.

Iskandar, W., dan Sunendar, D. (2011). Strategi Pembelajaran Bahasa. Bandung: PT. Remaja Rosdakarya.

Mulyati, Y. dkk. (2008). Keterampilan berbahasa Indonesia. Jakarta: Universitas Terbuka.

Suhendar. (2002). Panduan efektif belajar menulis. Bandung: Angkasa.

Tim Penyusun Kamus Pusat Bahasa. (2003). Kamus Besar Bahasa Indonesia. Jakarta: Balai Pustaka.

Tarigan, H. G. (2008). Menulis sebagai suatu keterampilan berbahasa. Bandung: Angkasa..

Rahman, F. (2018). Menulis Karangan Deskripsi dengan Model Pembelajaran Picture And Picture. El Banar: Jurnal Pendidikan dan Pengajaran, 1(01), 55-62. 
Imajeri: Jurnal Pendidikan Bahasa dan Sastra Indonesia

Vol. 02, No. 2, pp. 119-128; Maret 2020

ISSN 2654-4199

Yanti, P.G., Zabadi, F., dan Rahman, F. (2017). Bahasa Indonesia: Konsep dasar dan penerapan. Jakarta: Grasindo. 